\title{
Peningkatan Kemampuan Menulis Teks Ulasan Film Pendek pada Siswa dengan Strategi Think Talk Write
}

\section{Improving Students'Writing Skill of Short Films Reviews By Using Think- Talk-Write Strategy}

\author{
Aliza Keumala Devi \\ SMA Negeri 21, Bandung, Jawa Barat, Indonesia \\ alizakeumaladevi@gmail.com
}

Naskah diterima tanggal 15/3/2018, Direvisi akhir tanggal 16/7/2018, disetujui tanggal 15/8/2018

\begin{abstract}
Abstrak
Penelitian ini bertujuan untuk mendeskripsikan kualitas pembelajaran menulis dan peningkatan keterampilan menulis teks ulasan film pendek dengan strategi think talk write(TTW). Melalui strategi pembelajaran think talk write(TTW), peningkatan dapat dilihat dari aktivitas siswa dan hasil penlilaian pembelajaran.Penelitian ini merupakan penelitian tindakan kelas (PTK) yang telah dilaksanakan di SMA Negeri 21 Bandung. Subjek dalam penelitian ini adalah siswa kelas XI IPS2 yang terdiri atas 31 siswa. Penelitian ini dilakukan dalam tiga siklus yang terdiri dari empat tahap setiap siklusnya, yaitu perencanaan, tindakan, pengamatan, dan refleksi. Teknik pengumpulan data yang digunakan dalam penelitian ini meliputi, angket, observasi, tes, dan dokumentasi. Penelitian ini menggunakan teknik analisis data kualitatif dan kuantitatif. Hasil penelitian ini menunjukkan bahwa penerapan strategi think talk write(TTW) dapat meningkatkan keterampilan menulis teks ulasan film pendek siswa kelas XI IPS 2 SMA Negeri 21 Bandung. Peningkatan tersebut ditunjukkan dari kualitas proses aktivitas siswa dalam pembelajaran yang tercermin dalam perhatian siswa terhadap pembelajaran, gairah belajar siswa, keaktifan siswa terhadap pembelajaran, ketepatan waktu siswa dalam mengumpulkan tugas.
\end{abstract}

Kata kunci: kemampuan menulis, strategi think talk write, dan teks ulasan film pendek.

Abstract
This study aims to describe the quality of writing learning and the improvement of writing skills for short film review with a think talk write (TTW) strategy. Through a think-talk writing (TTW) strategy, improvements can be seen from student activities and learning outcomes. This research is a class action research (PTK) that has been implemented in SMA Negeri 21 Bandung. Subjects in this study were students of class XI IPS2 consisting of 31 students. This research was conducted in three cycles consisting of four stages in each cycle, namely planning, action, observation, and reflection. Data collection techniques used in this study include questionnaires, observation, tests, and documentation. This research uses qualitative and quantitative data analysis techniques. The results of this study indicate that the implementation of talk talk write (TTW) strategy, can improve the skills of writing the text of short film reviews of students of class XI IPS 2 SMA Negeri 21 Bandung. The improvement is indicated by the quality of student activity process in the learning which is reflected in the students' attention to the learning, the students'learning spirit, the students' activity toward the learning, the timeliness of the students in collecting the tasks.

Keywords: short film reviews, think talk write strategies, and writing capabilities.

\section{PENDAHULUAN}

Keterampilan menulis merupakan suatu bentuk manifestasi kemampuan dan keterampilan berbahasa yang paling akhir dikuasai oleh pembelajar bahasa setelah keterampilan menyimak, keterampilan berbicara, dan keterampilan membaca (Iskandarwassid \& Sunendar, 2009:248).
Dalam hal ini, sejalan dengan Nurjamal (2011:4) keterampilan menulis dapat dikatakan sebagai kemampuan puncak seseorang dalam terampil berbahasa setelah keterampilan menyimak, berbicara, dan membaca. Keterampilan menulis dibandingkan dengan tiga keterampilan berbahasa lebih sulit dikuasai bahkan oleh 
penutur asli bahasa yang bersangkutan sekalipun. Hal ini dikarenakan keterampilan menulis menghendaki penguasaan berbagi unsure kebahasaan dan unsur diluar bahasa itu sendiri yang akan menjadi tulisan (Maghfiroh, 2016; Safitri, 2017). Baik unsur bahasa maupun unsur isi haruslah terjalin sedemikian rupa sehingga menghasilkan tulisan yang runtut dan padu (Nasution, 2016).

Pembelajaran bahasa Indonesia dalam keterampilan menulis pada siswa SMA kelas XI dalam kurikulum mencakup menulis teks cerpen, pantun, cerita ulang biografi, eksplanasi, dan ulasan film dan drama. Salah satu keterampilan menulis yang harus dipelajari adalah menulis teks ulasan film dan drama.Teks ulasan film dan drama merupakan teks yang berisi kritikan terhadap hasil karya film maupun drama yang disampaikan secara santun, dengan pemilihan kata yang baik, dan pada waktu yang tepat. Teks ini mengajarkan siswa untuk menguasai permasalahan yang dikritik dan juga siswa memberikan solusi terhadap permasalahan yang dihadapi (Kementrian Pendidikan dan Kebudayaan Republik Indonesia, 2014:51).

Pada dasarnya film dan drama tidak jauh berbeda. Namun, ada beberapa faktor yang membuat peneliti memfokuskan penelitian terhadap teks ulasan film, khususnya film pendek. Faktor tersebut di antaranya durasi film pendek yang kurang dari 60 menit sehingga membuat waktu pembelajaran menjadi lebih efektif, serta film pendek tidak memakan banyak tempat karena film pendek hanya ditayangkan dan tidak dipentaskan. Selain itu, materi teks ulasan drama juga sudah diajarkan oleh guru. Film pendek yang dipilih dalam penelitian ini meliputi, Slap Her Childrens Reactions, My Dad is a Liar, dan The Black Hole. Peneliti memilih ketiga judul film pendek tersebut karena ketiga judul film pendek yang dipilih dalam penelitian ini memiliki nilai-nilai pendidikan karakter yang dapat dipelajari dan diterapkan oleh siswa.

Pembelajaran menulis teks ulasan film pendek pada siswa kelas XI IPS2 SMA Negeri 21 Bandung memerlukan adanya strategi yang tepat sebagai solusi untuk mengatasi permasalahan yang dikritik dan juga siswa memberikan solusi terhadap permasalahan yang dihadapi dalam menulis. Peneliti menerapkan strategi think talk write untuk meningkatkan keterampilan siswa dalam menulis teks ulasan film pendek. Strategi yang pertama kali diperkenalkan oleh Huinker dan Laughlin adalah strategi think talk write (Viqriah, Subanti, \& Budiyono, 2015). Strategi ini didasarkan pada pemahaman bahwa belajar adalah perilaku sosial. Huinker menyatakan bahwa strategi think talk write adalah sebuah pembelajaran yang dimulai dengan berpikir melalui bahan bacaan menyimak, mengkritisi, dan solusi alternatif, kemudian hasil bacaan dikomunikasikan dengan presentasi, diskusi, dan tahap akhir membuat laporan hasil presentasi (Sumirat, 2014). Strategi think talk write mempunyai keunggulan dalam pembelajaran menulis teks ulasan film pendek. Strategi think talk write tidak hanya membentuk siswa belajar secara mandiri namun juga membentuk siswa belajar secara berkelompok (Nuary, 2018). 
Terdapat beberapa penelitian terdahulu yang mendukung strategi think talk write dalam peningkatan kemampuan menulis peserta didik, diantaranya adalah penelitian F. W. Putri (2016); Tifani, Atmazaki, \& Nursaid (2017); Mauk (2017); Mursida (2010); dan L. S. Putri (2016)

Rumusan masalah pokok dalam penelitian ini adalah Apakah pembelajaran dengan menggunakan strategi Think talk write dapat meningkatkan ketrampilan siswa dalam menulis teks ulasan film pendek? sedangkan tujuan penelitian adalah mengetahui pemahaman konsep siswa dalam pembelajaran ketrampilan menulis teks ulasan film pendek dengan strategi think talk write. Serta mengetahui respon siswa setelah pembelajaran berlangsung.

\section{METODE PENELITIAN}

\section{Desain Penelitian}

Penelitian ini menggunakan penelitian tindakan kelas (classroom action research). Penelitian ini mengacu pada pedoman model penelitian tindakan kelas Kemmis dan Taggart. Model Kemmis dan Taggart mencakup perencanaan (planning), tindakan (acting), observasi (observing), dan refleksi (reflecting). Penelitian ini akan dilakukan dalam siklus bertahap sesuai dengan kondisi lapangan saat penelitian hingga tercapainya tujuan penelitian (Prof. Dr. Sugiyono, 2016:76).

\section{Setting Penelitian}

Dilaksanakan di SMA Negeri 21 Bandung, yang beralamat di Jalan Manjahlega No 29 Rancasawo Ciwastra Bandung, direncanakan dilakukan pada bulan Agustus 2016 sampai
Januari 2017. Subjek penelitian ini adalah siswa kelas XI IPS2 Tahun Pelajaran 2016/2017, yang berjumlah 31 siswa dengan jumlah laki laki 17 siswa dan jumlah perempuan 14 siswa. Penelitian ini menggunakan tiga judul film pendek. Pada setiap siklusnya diputar satu film pendek. Ketiga judul film pendek dalam penelitian ini, sebagai berikut. Slap Her Childrens Reactions, My Dad is a Liar, The Black Hole

\section{Teknik Pengumpulan Data dan Instrumen Penelitian}

Tes, Instrumen tes yang dilengkapi dengan kisi-kisi soal, perangkat soal dan lembar jawab soal. Lembar Observasi, dilengkapi dengan pedoman observasi yang digunakan untuk mengamati proses pembelajaran yang sedang berlangsung dan Angket

\section{Teknik Analisis Data Kualitatif}

Analisis data kualitatif diperoleh dari aktivitas siswa dalam pembelajaran, yaitu aktivitas siswa dilihat dari aktivitas individu, aktivitas kelompok, dan aktivitas antar kelompok. Aktivitas individu siswa meliputi perhatian terhadap pembelajaran, semangat belajar, keaktifan bertanya jawab, keaktifan mengerjakan tugas, keaktifan menyunting tulisan, dan ketepatan waktu mengumpulkan tugas.

\section{Teknik Analisis Data Kuantitatif}

Adapun rumus yang digunakan adalah: Untuk menghitung nilai rata-rata menggunakan rumus $\bar{x}=\frac{\sum x}{N} X=$ rata-ratanilai, $\sum x=$ jumlah seluruh nilai, $N=$ jumlah siswa

Kriteria penilaian. $<50 \%=$ Rendah, $51 \%$ $74 \%=$ kurang, $75 \%-84 \%=$ Baik, $\geq 85=$ Sangat Baik. 


$$
\begin{aligned}
& \text { Menghitung ketuntasan belajar } \\
& \text { persentase }(\%)=\frac{\text { Jumlah skor yang diperoleh }}{\text { Jumlah skor maksimal }} \times 100 \%
\end{aligned}
$$

\section{Kriteria Keberhasilan Tindakan}

Indikator keberhasilan dalam penelitian ini apabila 75\% siswa di kelas mendapatkan nilai lebih besar dari KKM atau sama besar dengan nilai KKM. (KKM Bahasa Indonesia, $\geq 75$ ) Pencapaian indikator keberhasilan dikatakan meningkat apabila data menunjukkan bahwa indikator keberhasilan pada siklus kedua lebih besar dari indicator keberhasilan pada siklus yang pertama dan seterusnya.

\section{HASIL DAN PEMBAHASAN}

\subsection{Hasil}

1. SiklusI

Siklus I dilaksanakan sebanyak $2 \mathrm{x}$ pertemuan, yaitu pada hari Kamis tanggal6 Oktober 2016 dan hari Senin tanggal 10 Oktober 2016. Berikut tahapan siklus I sesuai dengan tindakan kelas model spiral Kemmis dan Taggart (plan, act, observer, and reflect).

a. Perencanaan Siklus I (Plan)

Menyiapkan pembelajaran, menentukan bahan penulisan teks ulasan yang berupa filmpendek, yang berjenis fiksi dan mempunyai durasi yang singkat. Judul film pendek tersebut adalah Slap Her Childrens Reactions. Membuat RPP. Menyiapkan instrumen penilaian. Menyiapkan alat bantu mengajar yang diperlukan. Menentukan waktu pelaksanaan penelitian untuk setiap siklus

b. Tindakan Siklus I (Act)

Siklus I pertemuan pertama (Kamis, 6 Oktober 2016), guru melakukan apersepsi dan menyampaikan tujuan pembelajaran, mengondisikan siswa, meminta siswa untuk membuat enam kelompok, Siswa dibuat menjadi kelompok diharapkan untuk berdiskusi menyamakan presepsi masing-masing yang diperoleh dari bahan catatan simakan dari film film pendek Slap Her Childrens Reactions. Tahapan kelompok termasuk ke dalam tahap talk pada strategi think talk write. Siswa kemudian diminta untuk menulis teks ulasan film pendek Slap Her Childrens Reactions. Melakukan refleksi mengenai pembelajaran yang telah dilakukan. Siklus I pertemuan kedua (Senin, 10 Oktober 2016) Guru memberikan kesempatan pada siswa untuk menyelesaikan teks ulasan film pendek Slap Her Childrens Reactions. Siswa setelah menyelesaikan tugas menulis teks ulasan film pendek kemudian menukarkan hasil tulisannya kepada teman sebangku dan saling menyunting tulisan seperti. Siswa lalu menuliskan kembali tulisan yang sudah disunting temannya menjadi tulisan jadi. Tahapan menulis teks ulasan film pendek ini termasuk ke dalam tahapan write dalam strategi think talk write. Guru menyampaikan refleksi mengenai pembelajaran siklus I dengan memberikan motivasi dan saran. Guru menutup pembelajaran.

c. Pengamatan Siklus I (Observer)

Hasil pengamatan yang dilakukan observer terhadap siswa, adalah aspek pertama, siswa tidak banyak memperhatikan guru dalam proses pembelajaran. Mereka asyik 
main HP dan ngobrol dengan temannya, aspek kedua yaitu banyak siswa kurang semangat. Siswa kurang semangat karena pembelajaran yang kurang menarik dan membosankan. Aspek ketiga, siswa cukup aktif dalam bertanya menyunting tulisan, dan menjawab pertanyaan guru.
Aspek keempat, dua puluh lima persen siswa mengumpulkan tugas tepat waktu. Banyak siswa yang belum mengumpulkan tugas dengan tepat waktu. Waktu yang diperlukan guru dalam pembelajaran tidak cukup. Guru belum membimbing siswa saat berdiskusi secara menyeluruh

Tabel 1. Persentase Hasil Penilaian Tiap Aspek Siklus I

\begin{tabular}{lllllll}
\hline \multirow{2}{*}{ No } & \multicolumn{1}{c}{ Aspek } & Jml & Rata2 & Nilai Maks & $\%$ & Kategori \\
\hline 1 & Kreativitas tulisan film & 63 & 2,03 & 20 & $10,15 \%$ & Rendah \\
\hline 2 & Kelengkapan informasi & 291 & 9,38 & 15 & $62,53 \%$ & Kurang \\
\hline 3 & Struktur teks ulasan & 564 & 18,19 & 20 & $90,95 \%$ & Sangat Baik \\
\hline 4 & Pemilihan kata & 216 & 6,96 & 15 & $46,4 \%$ & Rendah \\
\hline 5 & Penulisan kalimat & 317 & 10,22 & 20 & $51,1 \%$ & Kurang \\
\hline 6 & Penulisan ejaan & 174 & 5,61 & 10 & $56,1 \%$ & Kurang \\
\hline
\end{tabular}

Pada tabel 1 tindakan siklus I dengan strategi think talk write belum mencapai hasil maksimal. Hal ini dikarenakan pada aspek pemilihan kata berkategori rendah yaitu sebesar 46,4\%. Pada aspek penulisan kalimat dengan prosentase $51,1 \%$ dan penulisan ejaan dengan prosentase $56,1 \%$ dan masih dalam kategori kurang. Maka penggunaan aspek penilaian dalam tulisan siswa dapat berpengaruh pada nilai siswa. Oleh karena itu, pada tindakan siklus II, ketiga aspek penilaian yang rendah dan kurang harus lebih ditingkatkan.

d. Refleksi Siklus I (Reflect)

Tabel 2. Siklus I Nilai Hasil Belajar Siswa Kelas XI IPS

\begin{tabular}{lcc}
\hline \multicolumn{1}{c}{ Hasil Belajar } & Nilai \\
\hline Jumlah skor/ rata rata nilai & 1625 & 52,41 \\
\hline Nilai tertinggi/ nilai terendah & 64 & 45 \\
\hline Jumlah tuntas / \% tuntas & 0 & $0 \%$ \\
\hline Jumlah tidak Tuntas/ \% tidak tuntas & 31 & $100 \%$ \\
\hline Persen Ketuntasan Klasikal & $100 \%$ & \\
\hline
\end{tabular}

Berdasarkan pada Tabel 2 dapat ditarik kesimpulan bahwa hasil produk perlu peningkatan karena 31 siswa belum mencapai kriteria ketuntasan minimal (KKM) Nilai rata rata kelas adalah 52,41, dengan perolehan nilai terendah 45 dan nilai tertinggi 64. Berdasarkan analisis hasil belajar siswa bahwa rata-rata nilai kelas XI IPS2 belum mencapai indikator keberhasilan $75 \%$. Sehingga perlu adanya perbaikan pada siklus selanjutnya. Adanya kendala pada siklus I saat proses pembelajaran Jurnal Penelitian Pendidikan

berlangsung juga menjadi kekurangan pada tindakan. Kendala tersebut didiskusikan peneliti bersama observer untuk mencari jalan keluar dalam siklus berikutnya. Kendala yang dihadapi pada siklus I ini adalah siswa kurang memahami struktur, isi, dan informasi teks ulasan film pendek. Siswa kurang menguasai pemilihan kata dan pemilihan kalimat yang baik dan benar. Siswa kurang menguasai EYD dan tanda baca yang benar. Permasalahan atau kendala-kendala yang terjadi pada 
siklus I akan menjadi dasar perbaikan dan pemfokusan perencanaan di siklus II.

2. SiklusII

a. Perencanaan Siklus II (Plan)

Langkah-langkah yang dilaksanakan pada`siklus II adalah mempersiapkan materi mengenai struktur dan ciri kebahasaan teks ulasan film pendek. Penekanan kembali materi ini disusun berdasarkan kekurangan yang terdapat dalam menulis teks ulasan film pendek siswa yang tidak runtut dan tidak lengkap. Mempersiapkan instrumen yang akan digunakan dalam siklus II seperti RPP, lembar kerja siswa, lembar observasi, catatan lapangan, dan daftar nilai siswa dengan mempertimbangkan alokasi waktu. Filmpendek yang digunakan dalam siklus II ini berjudul My Dad is a Liar. Pemilihan film tersebut disesuaikan dengan hal yang dekat dengan kehidupan siswa sehingga diharapkan dapat mudah dipahami dan dikembangkan menjadi teks ulasan film pendek.

\section{b. Tindakan Siklus II}

Siklus II Pertemuan Pertama (Kamis, 13 Oktober 2016). Guru mengulas kembali kegiatan yang telah dilakukan pada siklus I, menjelaskan mengenai aspek-aspek yang harus diperhatikan dalam menulis teks ulasan film pendek. Film pendek yang akan diputar oleh guru berjudul My Dad is a Liar. Siswa kemudian mencermati struktur, isi, dan informasi penting yang terkait dengan film pendek yang diputar. Siswa selanjutnya mencatat struktur, isi, dan informasi penting yang terkait dengan film pendek yang diputar. Pada tahap ini siswa sudah melakukan tahap think dalam strategi Think Talk Write dimana siswa mampu berpikir untuk mencermati struktur, isi, dan informasi penting yang terkait dengan film pendek yang diputar. Siswa berdiskusi dengan teman kelompok Pada tahap ini banyak siswa yang bertanya kepada guru mengenai struktur teks ulasan film pendek. Siswa terlihat bingung dan masih belum paham mengenahi struktur teks ulasan film pendek. Hal ini termasuk pada tahap talk dalam strategi Think Talk Write, dimana siswa menganggap bahwa menulis ulang ulasan itu adalah menulis kembali teks ulasan karya orang lain dengan kalimat yang sama seperti contoh teks ulasan film yang diberikan guru. Siswa masih belum paham dengan struktur teks ulasan ini apakah harus runtut atau tidak. Siswa mendapat instruksi guru untuk menuliskan film pendek yang diputar dengan mengaitkan hasil pencermatan dan diskusi. Guru dan siswa melakukan refleksi terhadap pembelajaran yang telah dilakukan. Siklus II Pertemuan Kedua (Senin, 17 Oktober 2016). Guru memberi waktu satu jam pertama untuk siswa menyelesaikan hasil tulisannya. Satu jam berikutnya, siswa setelah menyelesaikan tugas menulis teks ulasan film pendek kemudian menukarkan hasil tulisannya kepada teman sebangku dan saling menyunting tulisan seperti. Siswa lalu menuliskan kembali tulisan yang sudah disunting temannya menjadi tulisan jadi. Guru terus mengingatkan siswa untuk memperhatikan struktur teks ulasan film pendek yang digunakan secara runtut dan lengkap. Seluruh siswa telah menyelesaikan tulisan teks ulasan film pendek. Siswa kemudian mengumpulkan hasil teks ulasan film pendek dimeja 
guru. Guru kemudian melakukan refleksi terhadap pembelajaran yang telah dilakukan. Guru kemudian menyampaikan pembelajaran selanjutnya dan menutup pelajaran dengan salam.

\section{c. Pengamatan Siklus II (Observe)}

Perhatian siswa terhadap pembelajaran maupun pemutaran film pendek semakin meningkat. Siswa diam, tidak asyik dengan main handphone, dan fokus untuk menonton film pendek. Siswa mencermati struktur, isi, informasi penting yang terkait dengan film yang sedang diputar. Aspek pertama menunjukkan seluruh siswa memperhatikan guru dalam proses pembelajaran. Siswa terlihat fokus melihat film yang sedang diputar. Aspek kedua, siswa bersemangat mengikuti proses pembelajaran. Siswa tidak sabar untuk menonton film pendek My Dad is a Liar. Aspek ketiga menunujukkan siswa aktif dalam berkelompok. Strategi Think Talk Write juga mengajarkan siswa untuk belajar kelompok termasuk tahap talk. Siswa dalam tahap talk mengkomunikasikan, berdiskusi, bertanya jawab, saling bertukar pikiran, menyamakan persepsi mengenai isi dan informasi film My Dad is a Liar. Aspek keempat menunjukkan $70 \%$ siswa mengumpulkan tugas tepat waktu. Hasil penilaian teks ulasan film pendek siswa pada siklus II. Berikut hasil penilaian tiap aspek.

Tabel 3. Persentase Hasil Penilaian Tiap Aspek Siklus II

\begin{tabular}{ccccccc}
\hline No. & \multicolumn{1}{c}{ Aspek } & Jumlah & Rata- rata & Nilai Maks. & Presentase & Kategori \\
\hline 1. & Kreativitas tulisan film & 520 & 16,77 & 20 & $83,85 \%$ & Sangat Baik \\
\hline 2. & Kelengkapan informasi & 368 & 11,87 & 15 & $79,13 \%$ & Baik \\
\hline 3. & Struktur teks ulasan & 533 & 17,19 & 20 & $85,95 \%$ & Sangat Baik \\
\hline 4. & Pemilihan kata & 280 & 9,03 & 15 & $60,2 \%$ & Kurang \\
\hline 5. & Penulisan kalimat & 392 & 12,64 & 20 & $63,2 \%$ & Kurang \\
\hline 6. & Penulisan ejaan & 229 & 7,38 & 10 & $73,8 \%$ & Kurang \\
\hline
\end{tabular}

Berdasarkan persentase aspek penilaian siklus II pada Tabel 3, maka dapat disimpulkan sebagai berikut. Tindakan siklus II dengan strategi Think Talk Write belum mencapai hasil maksimal. Hal ini dikarenakan pada aspek pemilihan kata $(60,2 \%)$, penulisan kalimat $(63,2 \%)$, dan penulisan ejaan $(73,8 \%)$ masih dalam kategori kurang. Dengan demikian, penggunaan aspek penilaian dalam tulisan siswa dapat berpengaruh pada nilai siswa. Oleh karena itu, pada tindakan siklus II, ketiga aspek penilaian yang masih kurang harus lebih ditingkatkan.

\section{d. Refleksi Siklus II (Reflect)}

Jurnal Penelitian Pendidikan
Tindakan pada siklus II sudah mulai terlihat beberapa peningkatan, yaitu peningkatan proses dan produk. Peningkatan proses ini dapat dilihat dari hasil pengamatan yaitu meningkatnya perhatian siswa terhadap pembelajaran kemampuan berpikir siswa untuk mencermati unsurunsur dan isi film pendek, kemampuan siswa dalam menyampaikan pemahaman tentang film pendek, dan ketelitian siswa dalam komposisi menulis. Peningkatan produk dapat dilihat dari peningkatan hasil belajarsiswa. Berikut adalah penilaian ketuntasan siswa dalam menulis teks ulasan film pendek. 


\begin{tabular}{|c|c|c|}
\hline Hasil Belajar & \multicolumn{2}{|c|}{ Nilai } \\
\hline Jumlah skor/ rata rata nilai & 2322 & 74,90 \\
\hline Nilai tertinggi/ nilai terendah & 85 & 60 \\
\hline Jumlah tuntas / \% tuntas & 21 & $67,74 \%$ \\
\hline Jumlah tidak Tuntas/ \% tidak tuntas & 10 & $32,26 \%$ \\
\hline
\end{tabular}

Berdasarkan penilaian ketuntasan siklus II pada Tabel 4, maka dapat ditarik kesimpulan bahwa meskipun hasil penilaian sudah meningkat dari tahap siklus I, namun nilai ketuntasan masih di bawah $75 \%$ dari jumlah siswa. Nilai tuntas baru didapatkan 21 siswa atau sebesar $67,74 \%$, nilai siswa yang belum tuntas sebanyak 10 siswa $(32,26 \%)$ dan nilai tertinggi 85 sedangkan nilai terendah 60 . Nilai rata-rata hasil belajar siklus II juga masih di bawah KKM, yaitu 74,90. Dengan demikian, masih perlu ditingkatkan pada siklus selanjutnya. Adanya kendala pada siklus II saat proses pembelajaran berlangsung menjadi kekurangan pada tindakan. Kendala tersebut didiskusikan peneliti bersama observer untuk mencari jalan keluar dalam siklus berikutnya. Permasalahan atau kendala-kendala yang terjadi pada siklus II akan menjadi dasar perbaikan dan pemfokusan perencanaan di siklus III.

3. Siklus III

a. Perencanaan Siklus III (Plan)

Perencanaan dalam siklus III ini bertujuan untuk memperbaiki kekurangan yang masih terjadi dalam siklus II. Selain berupaya untuk memperbaiki dalam segi proses pembelajaran, dalam siklus III ini peneliti dan observer juga akan berupaya untuk memaksimalkan lagi keterampilan siswa dalam setiap aspek tulisan teks ulasan film pendek sehingga keterampilan menulis teks ulasan film pendek akan semakin meningkat dan nilai rata-rata siswa sebesar lebih dari 75\% mencapai di atas KKM.

b. Tindakan Siklus III (Act)

Siklus III, Kamis, 20 Oktober 2016. Judul film pendek yaitu, The Black Hole. Guru memberi apersepsi, menerangkan kembali ciri kebahasaan, penggunaan EYD dan tanda baca yang benar untuk menulis teks ulasan film pendek. Siswa mencatat struktur, isi, dan informasi penting yang terkait dengan film pendek yang diputar. Pada tahap ini siswa sudah melakukan tahap think dalam strategi Think Talk Write dimana siswa mampu berpikir untuk mencermati struktur, isi, dan informasi penting yang terkait dengan film pendek yang diputar. Guru kemudian menginstruksikan siswa berdiskusi dengan teman kelompok agar siswa dapat menyamakan persepsi, saling bertanya tanpa harus bertanya kepada guru. Pada tahap ini tidak ada siswa yang bertanya kepada guru mengenai struktur teks ulasan film pendek. Siswa mulai terlihat mandiri dan sudah bisa memahami struktur teks ulasan film pendek. Hal ini termasuk pada tahap talk dalam strategi Think Talk Write, dimana siswa aktif dalam berbicara, mendiskusikan, bertanya, memberi komentar tentang film pendek yang sudah diputar. Guru memberi waktu menyelesaikan hasil tulisannya. Setelah menyelesaikan tugasnya kemudian menukarkan hasil tulisannya kepada teman 
sebangku dan saling menyunting tulisan seperti. Siswa lalu menuliskan kembali tulisan yang sudah disunting temannya menjadi tulisan jadi. Seluruh siswa telah menyelesaikan tulisan teks ulasan film pendek. Siswa kemudian mengumpulkan hasil teks ulasan film pendek dimeja guru. Selanjutnyamembagikanangketpada siklus III kepada siswa. Setelah pengisiian angket selesai, guru melakukan refleksi terhadap pembelajaran yang telah dilakukan dan menyampaikan pembelajaran selanjutnya dan menutup pelajaran dengan salam.

c. Pengamatan Siklus III (Observe)
Melalui hasil analisis dari pengamatan ini, dapat diketahui Aspek pertama menunjukkan seluruh siswa memperhatikan guru dalam proses pembelajaran. Aspek kedua siswa bersemangat mengikuti proses pembelajaran sejak awal sampai akhir. Aspek ketiga siswa aktif secara mandiri maupun berkelompok. Aspek keempat seratus persen siswa mengumpulkan tugas tepat waktu. Berdasarkan hasil penilaian siswa siklus III pada Tabel 5 dapat diketahui analisis persentase aspek penilaian siklus III sebagai berikut.

Tabel 5. Persentase Hasil Penilaian Tiap Aspek Siklus III

\begin{tabular}{clccccc}
\hline No. & \multicolumn{1}{c}{ Aspek } & Jumlah & Rata-rata & Nilai & Presentase & Kategori \\
\hline 1. & Kreativitas tulisan film & 536 & 17,29 & 20 & $86,45 \%$ & Sangat Baik \\
\hline 2. & Kelengkapan informasi & 382 & 12,32 & 15 & $82,13 \%$ & Sangat Baik \\
\hline 3. & Struktur teks ulasan & 587 & 18,93 & 20 & $94,65 \%$ & Sangat Baik \\
\hline 4. & Pemilihan kata & 351 & 11,32 & 15 & $75,46 \%$ & Baik \\
\hline 5. & Penulisan kalimat & 466 & 15,03 & 20 & $75,15 \%$ & Baik \\
\hline 6. & Penulisan ejaan & 249 & 8,03 & 10 & $80,3 \%$ & Baik \\
\hline
\end{tabular}

Berdasarkan persentase aspek penilaian siklus III pada Tabel 5, menunjukkan tiga aspek penilaian yang berkategori sangat baik di antaranya, aspek kreativitas tulisan film sebesar 86,45\%, aspek kelengkapan informasi sebesar 82,13\%, dan aspek struktur teks ulasan sebesar 94,65\%. Tiga aspek lain yang berkategori baik di anataranya pemilihan kata sebesar $75,46 \%$, penulisan kalimat sebesar $75,15 \%$, dan penulisan ejaan sebesar $80,3 \%$.

d. Refleksi Siklus III (Reflect).

Hasil tindakan pada siklus III lebih baik dibandingkan dengan siklus II.
Keberhasilan proses dilihat dari siswa yang sudah mandiri dalam pembelajaran menulis teks ulasan film pendek. Siswa sudah tidak lagi bertanya mengenai materi yang diajarkan. Siswa lebih fokus dalam pembelajaran terlebih lagi saat pemutaran film pendek di kelas. Kreativitas siswa dalam penulisan teks ulasan film pendek sudah berkembang. Siswa sudah kritis dalam mencermati struktur, isi, ciri bahasa, informasi yang berkaitan dengan film yang diputar. Selanjutnya, peningkatan juga dapat dilihat dari hasil tulisan teksulasan film pendek.

Tabel 6. Siklus III Nilai Hasil Belajar Siswa Kelas XI IPS

\begin{tabular}{lcc}
\hline \multicolumn{1}{c}{ Hasil Belajar } & Nilai \\
\hline Jumlah skor/ rata rata nilai & 2571 & 82,87 \\
\hline Nilai tertinggi/ nilai terendah & 94 & 70 \\
\hline Jumlah tuntas / \% tuntas & 28 & $90,32 \%$ \\
\hline Jumlah tidak Tuntas/ \% tidak tuntas & 3 & $9,68 \%$ \\
\hline
\end{tabular}


Berdasarkan tabel 6 Dilihat dari segi dilihat dari $\geq 75 \%$ jumlah siswa di kelas produk, pada siklus III ini nilai siswa sudah di atas nilai $K K M \geq 75$. Rata-rata kelas mencapai 82,87 dengan kategori tuntas. Jumlah siswa yang tuntas yaitu $90,32 \%$, artinya penelitian ini sudah berhasil. sangat baik. Peningkatan nilai ini diperoleh

\subsection{Pembahasan} dari peningkatan penulisan struktur, isi,

1. Perbandingan Kemampuan Menulis cirri bahasa teks ulasan film pendek. Teks Ulasan Film Pendek

Keberhasilan penilaian hasil belajar dapat

Tabel 7. Perbandingan Hasil Belajar Siswa Tiap Aspek

\begin{tabular}{clllc}
\hline No. & \multicolumn{1}{c}{ Aspek } & Siklus I & Siklus II & Siklus II \\
\hline 1. & Kreativitas teks ulasan film & $10.15 \%$ & $83,85 \%$ & $86,45 \%$ \\
\hline 2. & Kelengkapan informasi & $62.53 \%$ & $79,13 \%$ & $82,13 \%$ \\
\hline 3. & Struktur teks ulasan film & $90.95 \%$ & $85,95 \%$ & $94,65 \%$ \\
\hline 4. & Pemilihan kata & $46.40 \%$ & $60,2 \%$ & $75,46 \%$ \\
\hline 5. & Penulisan kalimat & $51.10 \%$ & $63,2 \%$ & $75,15 \%$ \\
\hline 6. & Penulisan ejaan & $56.10 \%$ & $73,8 \%$ & $80,3 \%$ \\
\hline
\end{tabular}

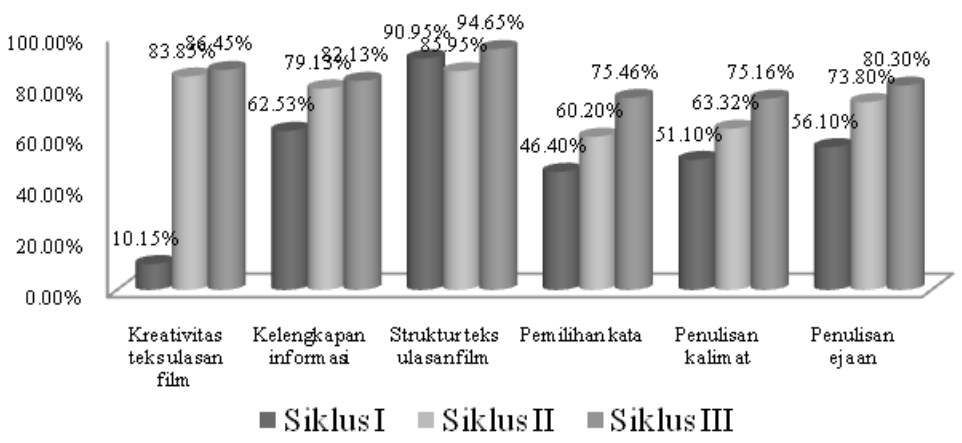

Grafik 1. Perbandingan Hasil Belajar Siswa Tiap Aspek Siklus I, Siklus II Siklus III

Berdasarkan tabel 7 dan grafik 1 dapat dijelaskan perkembangan tindakan tiap sikus sebagai berikut:

a. Tindakan Siklus I

Aspek kreativitas tulisan film pada siklus I memiliki persentase sebesar 81,75\%, termasuk dalam kategori baik. Siswa dalam penulisan teks ulasan film pendek dengan pembelajaran yang menggunakan strategi think talk write, mulai dapat mengembangkan ide secara kreatif. Hal ini terlihat penulisan siswa yang tidak mengacu pada contoh teks ulasan film pendek karya orang lain. Siswa lebih secara leluasa mengevaluasi film yang sudah pernah ditonton. Terbukti dengan pemilihan judul penulisan teks ulasan film yang kreatif, tidak harus sama persis dengan judul film pendek. Aspek kelengkapan informasi film pada siklus I memiliki persentase 79,53\%. termasuk dalam kategori cukup. Aspek ini mencakup latar belakang pembuatan film, produser film, waktu produksi film, pemeran film, dan durasi film.

Aspek struktur teks ulasan film pendek pada siklus I memiliki persentase sebesar $78,05 \%$, termasuk dalam kategori cukup, siswa tidak memperhatikan struktur teks ulasan film pendek. Struktur teks ulasan film pendek siswa, ada yang tidak runtut, Jurnal Penelitian Pendidikan 
ada juga yang tidak lengkap. Pada hasil penulisan siswa yang terdapat pada lampiran, struktur teks ulasan tidak lengkap dan tidak runtut. Struktur teks ulasan film bagian evaluasi dan rangkuman tidak ditulis, sedangkan struktur teks ulasan film bagian orientasi berada di paragraf awal dan paragraf akhir. Aspek pemilihan kata pada siklus I memiliki persentase 47,93\% tergolong rendah. Hampir seluruh siswa menggunaka kata konjungsi di awal kalimat. Kata konjungsi tersebut seperti, dalam, karena, setelah, dan. Aspek pemilihan kalimat pada siklus I memiliki persentase $65 \%$. Persentase tersebut tergolong kurang. Penulisan teks ulasan film pendek siswa, banyak yang tidak memperhatikan SPOK dalam kalimat. Siswa cenderung lebih menggunakann kata konjungsi di awal kalimat sehingga membuat kalimat tidak berstuktur SPOK.

Seperti pada hasil penulisan teks ulasan film pendek siswa, setelah anak-anak tersebut melakukan hal yang diperintahkan sang penanya. Seharusnya penulisan kalimat tersebut yang benar yaitu anakanak tersebut setelah melakukan hal yang diperintahkan sang penanya. Penilaian aspek penulisan ejaan memiliki persentase 69\%. Aspek ini meliputi criteria ejaan pada kata dan penulisan ejaan pada tanda baca. Penulisan kata ejaan pada kata dalam teks ulasan film siswa tahap siklus I masih banyak terjadi kesalahan. Pada penulisan judul teks ulasan film pendek siswa, penulisan Negara seperti italia, dan penulisan bulan seperti januari, awal huruf tidak kapital. Awal kata dari kalimat juga tidak menggunakan kapital.

\section{b. Tindakan Siklus II}

Aspek kelengkapan informasi film pada siklus II memiliki persentase 79,13\%. Persentase aspek kelengkapan informasi film pada siklus II menurun dari tahap siklus I dan masih termasuk dalam kategori cukup. Aspek ini mencakup latar belakang pembuatan film, produser film, waktu produksi film, pemeran film, dan durasi film. Hasil tulisan teks ulasan film pendek siswa di atas tidak menyertakan durasi dan waktu produksi film. Aspek struktur teks ulasan film pendek pada siklus II memiliki persentase sebesar 85,95\%. Persentase tersebut menunjukkan struktur teks ulasan film pendek meningkat dan termasuk dalam kategori baik. Penulisan teks ulasan film pendek siswa meningkat dikarenakan siswa mulai memperhatikan struktur teks ulasan film pendek. Pada hasil penulisan siswa yang terdapat pada lampiran, struktur teks ulasan tidak lengkap, namun sudah runtut. Struktur teks ulasan film bagian rangkuman tidak ditulis. Aspek pemilihan kata pada siklus II memiliki persentase 60,2\%. Persentase aspek penulisan kata pada siklus II meningkat dan tergolong kurang. Hampir seluruh siswa menggunakan kata konjungsi di awal kalimat. Kata konjungsi tersebut seperti, dalam, karena, setelah, dan, di.Aspek pemilihan kalimat pada siklus II memiliki persentase 63,2\%. Persentase tersebut menurun dan masih tergolong kurang.

Penulisan teks ulasan film pendek siswa, masih terdapat banyak singkatan kata konjungsi yang sebenarnya tidak boleh disingkat. Misalnya, Met Life adalah Asuransi Asia yg membuat film tentang 
gadis kecil yg menceritakan ayahnya.

Penilaian aspek penulisan ejaan memiliki persentase 69\%. Aspek ini meliputi criteria ejaan pada kata dan penulisan ejaan pada tanda baca. Penulisan kata ejaan pada kata dalam teks ulasan film siswa masih banyak terjadi kesalahan. Pada penulisan judul teks ulasan film pendek siswa yang tidak kapital, penulisan negara seperti thailand awal huruf tidak kapital. Awal kata dari kalimat juga tidak menggunakan kapital. Penulisan ejaan tanda baca juga belum diperhatikan. Setiap akhir kalimat tidak diakhiri dengan tanda baca titik(.).

c. Tindakan Siklus III

Pada siklus III, pembelajaran menulis teks ulasan film dengan menggunakan strategi

Think Talk Write dapat memperoleh hasil yang baik,yaitu hasil dari aktifitas siswa maupun hasil penilaian pembelajaran. Pengamatan dari aktifitas siswa membuktikan, siswa lebih mandiri dan tidak banyak bertanya kepada guru. Hal ini membuktikan bahwa siswa sudah memahami struktur dan ciri bahasa teks ulasan. Siswa juga lebih fokus dalam memperhatikan pelajaran, terlebih lagi saat pemutaran film pendek berlangsung. Dilihat dari hasil penilaian pembelajaran, sebanyak 90,32\% siswa tuntas dalam pembelajaran menulis teks ulasan film pendek. Hal ini dapat dilihat dari pembahasan sebagai berikut. Aspek kreativitas tulisan film pada siklus III memiliki persentase sebesar $86,45 \%$. Persentase tersebut menunjukkan aspek kreativitas pengembangan tulisan baik meningkat dan termasuk dalam kategori baik. Rata-rata siswa dapat mengembangkan ide secara kreativitas dengan menulis teks ulasan film pendek menggunakan bahasa sendiri. Siswa lebih kreatif dalam merangkai kalimat dan membuat judul teks ulasan film pendek.

Aspek kelengkapan informasi film pada siklus III memiliki persentase 82,13\%. Persentase aspek kelengkapan informasi film pada siklus III meningkat dari tahap siklus II dan termasuk dalam kategori baik. Aspek ini mencakup latar belakang pembuatan film, produser film, waktu produksi film, pemeran film, dan durasi film. Hasil tulisan teks ulasan film pendek siswa diatas, kelengkapan informasi film sudah lengkap. Aspek struktur teks ulasan film pendek pada siklus III memiliki persentase sebesar 94,65\%. Persentase tersebut menunjukkan struktur teks ulasan film pendek meningkat dan termasuk dalam kategori sangat baik, hal ini dikarenakan siswa mulai memperhatikan struktur teks ulasan film pendek. Pada hasil penulisan siswa di atas, struktur teks ulasan sudah lengkap dan sudah runtut.

Aspek pemilihan kata pada siklus III memiliki persentase $75,46 \%$. Persentase aspek penulisan kata pada siklus III meningkat dan tergolong cukup. Beberapa siswa menggunakan kata konjungsi diawal kalimat. Kata konjungsi tersebut seperti, dalam, karena, setelah, dan, di. Terdapat kata asing yang seharusnya ditulis miring. Aspek pemilihan kalimat pada siklus III memiliki persentase 75,15\%. Persentase tersebut meningkat dan tergolong cukup. Penulisan teks ulasan film pendek siswa dalam pemilihan kalimat sudah cukup. Penilaian aspek penulisan ejaan memiliki persentase $80,3 \%$. Persentase tersebut 
meningkat dan tergolong baik. Kesalahan penulisan ejaan terdapat pada singkatan kata $t d k$, yang sebenarnya tidak boleh disingkat. Penulisan ejaan didekatnya seharusnya dipisah tidak digabung Karena menunjukkan tempat.

2. Peningkatan Menulis Teks Ulasan Film Pendek dengan Strategi Think TalkWrite

Kriteria keberhasilan tindakan menulis teks ulasan film pendek dengan strategi Think

Tabel 8. Perbandingan Penilaian Siswa Siklus I, Siklus II dan Siklus III

\begin{tabular}{lccc}
\hline & \multicolumn{3}{c}{ Hasil Penilaian } \\
\cline { 2 - 4 } & Siklus I & Siklus II & Siklus III \\
\hline Jumlah & 1625 & 2322 & 2569 \\
\hline Rata rata & 52,41 & 74,90 & 82,87 \\
\hline Jumlah Ketuntasan & $0(0 \%)$ & $21(67,74 \%)$ & $28(90,32 \%)$ \\
\hline Jumlah Tidak Tuntas & $31(100 \%)$ & $10(32,26 \%)$ & $3(9,68 \%)$ \\
\hline Nilai Terendah & 45 & 60 & 70 \\
\hline Nilai Tertinggi & 64 & 85 & 94 \\
\hline
\end{tabular}

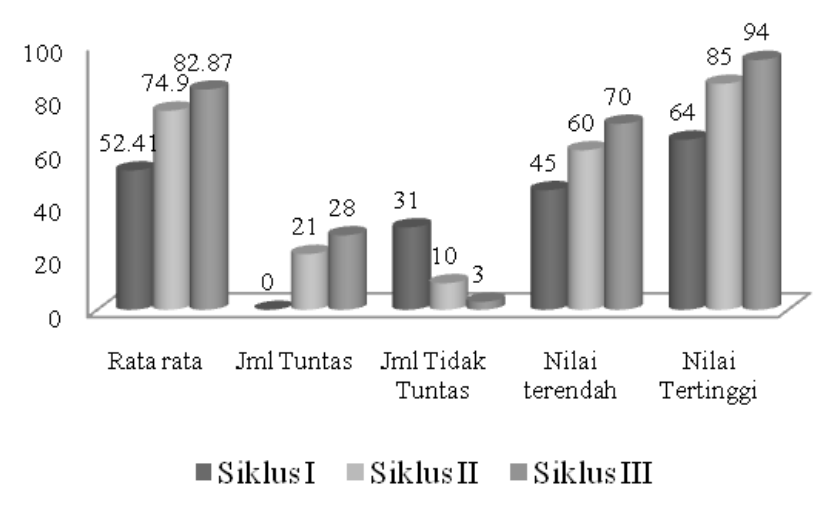

Grafik 2. Perbandingan Hasil Penilaian Siswa Siklus I, Siklus II dan Siklus III

Berdasarkan tabel 8 dan grafik 2 dapat diketahui bahwa, pada siklus I belum ada siswa yang tuntas. Nilai terndah siswa 45 dan nilai tertinggi 64. Pada siklus II nilai siswa meningkat sebanyak 21 siswa (67,74\%) tuntas dan 10 siswa (32,26\%). Nilai terendah pada siklus II adalah 60 dan nilai tertingginya 85 . Selanjutnya, pemberian tindakan siklus III nilai siswa meningkat sebanyak 28 siswa $(90,32 \%)$ tuntas, dan 3 siswa $(9,68 \%)$ tidak Jurnal Penelitian Pendidikan
Talk Write adalah terdapat peningkatan yang terkait dengan keterampilan menulis teks ulasan film pendek, yaitu dengan adanya peningkatan skala penilaian dari tiap siklus yang dilakukan. Dan siswa dapat dikatakan berhasil dalam pembelajaran ini, apabila siswa memperoleh nilai sesuai dengan $\mathrm{KKM}$ yaitu $\geq 75$. Berikut hasil penilaian siswa kelas XI IPS2 dalam menulis teks ulasan film pendek. 
Write. Dan indikator keberhasilan siswa secara klasikal sudah tercapai dan sesuai dengan KKM yaitu 75\% siswa di kelas mendapatkan nilai lebih besar dari KKM atau sama besar dengan nilai KKM, yaitu sebesar $\geq 75$.

\section{KESIMPULAN}

Peningkatan aktivitas pembelajaran menulis teks ulasan film pendek dengan menggunakan strategi think talk write pada siswa XI IPS1 SMA Negeri 21 Bandung mengalami peningkatan ke arah yang lebih baik, yaitu perhatian terhadap pembelajaran, gairah belajar siswa, keaktifan siswa terhadap pembelajaran, dan ketepatan waktu siswa dalam mengumpulkan tugas. Peningkatan proses pembelajaran terjadi secara bertahap dari siklus I, siklus II, siklus III. Aspek dalam proses pembelajaran yang paling dominan mengalami peningkatan adalah perhatian terhadap pembelajaran dan gairah belajar siswa. Peningkatan ini terjadi dikarenakan penggunaan strategi think talk write dalam pembelajaran menulis teks ulasan film pendek lebih menarik dan tidak membosankan sehingga siswa lebih memperhatikan pembelajaran.

Terdapat peningkatan hasil penilaian dari tiap siklusnya yaitu, pada siklus I belum ada siswa yang tuntas. Nilai terendah siswa 45 dan nilai tertinggi 64. Pada siklus II nilai siswa meningkat sebanyak 21 siswa $(67,74 \%)$ tuntas dan 10 siswa $(32,26 \%)$. Nilai terndah pada siklus II adalah 60 dan nilai tertingginya 85. Selanjutnya, pemberian tindakan siklus III nilai siswa meningkat sebanyak 28 siswa $(90,32 \%)$ tuntas, dan 3 siswa $(9,68 \%)$ tidak tuntas. Pada siklus III nilai terndah 70, sedangkan nilai tertinggi 94. Peningkatan nilai siswa dapat dilihat dari rata rata nilai tiap siklusnya, rata rata nilai siswa pada siklus I sebesar 52,41, pada siklus II meningkat sebesar 22,49 menjadi 74,90. Dari siklus II ke siklus III nilai meningkat menjadi sebesar 7,97 sehingga rata rata siklus III menjadi 82,87 .

\section{DAFTAR PUSTAKA}

Iskandarwassid, \& Sunendar, D. (2009). Strategi Pembelajaran Bahasa. Bandung : PT. Remaja Rosdakarya.

Kementrian Pendidikan dan Kebudayaan Republik Indonesia. (2014). bahasa indonesia ekspresi diri dan akademik untuk. Jakarta: Kementrian Pendidikan dan Kebudayaan Republik Indonesia.

Maghfiroh, M. (2016). Penerapan Metode Pembelajaran Picture and Picture Untuk Meningkatkan Keterampilan Menulis Karangan Pelajaran Bahasa Indonesia Kelas V MINU Ngingas Waru Sidoarjo. Universitas Islam Negeri Sunan Ampel.

Mauk, K. (2017). Peningkatan Kemampuan Menulis Teks Berita Melalui Strategi Think Talk Write (TTW) Dengan Menggunakan Foto Peristiwa Pada Peserta DIdik Kelas VIII A SMPN Rinbesihat Belu Tahun AJaran 2016/2017. Universitas Sanata Dharma, Yogyakarta.

Mursida. (2010). Peningkatan Kemampuan Membaca Pemahaman Melalui Strategi Pembelajaran Think-TalkWrite (TTW) Pada Pelajaran Bahasa Indonesia Siswa Kelas V SDN 027 Pulau Payung Kecamatan Rumbio Jaya Kabupaten Kampar. Universitas Islam Negeri Sultan Syarif Kasim Riau.

Nasution, F. A. (2016). Hubungan Penguasaan Kohesi dan Koherensi dengan Kemampuan Menulis Paragraf Argumentasi Pada Siswa Kelas X SMA Negeri 15 Medan Tahun Pembelajaran 2015/2016. Universitas Negeri Medan.

Nuary, I. G. (2018). Penerapan Strategi Think, Talk, Write Dalam Kosa Kata Bahasa Inggris Dengan Menggunakan Film. Proceeding of The URECOL, 150-156. 
Nurjamal, D. (2011). Terampil Berbahasa. Bandung : Alfabeta.

Prof. Dr. Sugiyono. (2016). Metode Penelitian Kuantitatif Kualitatif dan R\&D. Bandung: Alfabeta.

Putri, F. W. (2016). Peningkatan Keterampilan Menulis Teks Ulasan Film Pendek Dengan Strategi Think Talk Write (TTW) Pada Siswa Kelas XI IPS1 SMA Negeri 1 Sewon Bantul DIY. Universitas Negeri Yogyakarta.

Putri, L. S. (2016). Efektivitas Model Think Talk Write Terhadap Keterampilan Menulis Teks Negosiasi Siswa Kelas X Sekolah Menengah Atas Negeri 1 Bintan Tahun Pelajaran 2015-2016. Universitas Maritim Raja Ali Haji Tanjungpinang.

Safitri, I. (2017). Pembelajaran Menyusun Teks Ulasan Film dengan Menggunakan Model Think Talk Write pada Siswa Kelas VIII SMPIT Anni'mah Alkarimah Bandung Tahun Pelajaran 2016-2017. Universitas Pasundan.

Sumirat, L. A. (2014). Efektifitas Strategi Pembelajaran KooperatifTipe Think-Talk-Write (TTW) The Effectivenes Of A Cooperative Learning Strategy Think-Talk-Write Type On The Student's Compentence In Mathematical Communication And Disposition. Jurnal Pendidikan Dan Keguruan, 1(2), 21-29.

Tifani, Atmazaki, \& Nursaid. (2017). Pengaruh Penggunaan Teknik Think Talk Write ( TTW ) Terhadap Keterampilan Menulis Teks Cerita Ulang Biografi Siswa Kelas X Sma Negeri 14 Padang. Jurnal Pendidikan Basaha Dan Sastra Indonesia, 6(2), 374-382.

Viqriah, K., Subanti, S., \& Budiyono. (2015). Eksperimentasi Model Pembelajaran Think-Pair-Share (TPS), Think-Talk-Write (TTW) Dan Two Stay-Stray (TSTS) Pada Materi Bangun Ruang Sisi Datar Ditinjau Dari Self-Efficacy. JMEE, 5(2), 108-119. 